\title{
Consequences of Outsourcing Strategies on Employee Quality of Work Life, Attitudes, and Performance
}

Dean Elmuti

Eastern Illinois University • Charleston, Illinois Julian Grunewald

Eastern Illinois University • Charleston, Illinois Dereje Abebe

Eastern Illinois University • Charleston, Illinois

\begin{abstract}
Outsourcing is the strategic use of outside resources to perform activities that are usually handled by internal staff and resources. The consequences of implementing outsourcing strategies in an industrial setting were studied using a field study. This study was designed to explore both the financial as well as the human aspects of outsourcing activities. The attitudinal results of this research indicated that the outsourcing strategies had a negative impact on the perceived quality of work-life dimensions. The performance results presented here provide, at best, circumspect support for the claims of outsourcing proponents that the technique improves participants' performance and productivity. Although outsourcing can lead to certain gains for the organization, there are definitely human costs to be taken into account, and they should be considered as major factors contributing to the outsourcing debate, not just the financial aspects of organizations' decisions.
\end{abstract}

\section{Introduction}

Most corporations believe that in order to compete globally, they have to look at efficiency and cost containment rather than relying strictly on revenue increased (Bartlett, 2004; Drezner, 2004; Farrell \& Rosenfeld, 2005; Jasper, 2003). As companies seek to enhance their competitive positions in an increasingly global market place, they are discovering that they can cut costs and maintain quality by relying more on outside service providers for activities viewed as supplementary to their core businesses (Baily \& Farrell, 2004; Cassale, 1996; Donahoe \& Pecht, 2003; lrwin, 2004; Li \& Barnes, 2008). The trend is for outsourcing relationships to function more as partnerships. Outsourcing providers are taking increasing responsibility in realms that have traditionally remained as in-house, such as corporate strategy, information management, business investment, and internal quality initia- 
tives (Engardio, 2006). According to Gartner, an independent research company, the worldwide business process outsourcing segment will expand from $\$ 160.7$ billion in 2007 to $\$ 235.2$ billion by 2011 , a compound annual growth rate of $10.3 \%$ (Musico, 2008).

Several authors agree that if outsourcing is implemented with prior planning, it can result in lowering cost, increased capacity and productivity, and sometimes can lead to downsizing (Elmuti, 2003; Casale, 1996; Sinderman, 1995; Outlay \& Ranganathan, 2005). Perhaps the most common reason for taking noncore functions overseas in the United States is the lucrative cost-saving derived from allowing a job to be done by a professional employee(s) that are paid much lower than their U.S. counter parts (Jasper, 2003). Many companies that are taking manufacturing and service jobs from the U.S. also consider the lower tax rates, available in foreign countries compared to the higher rates in the U.S. (Donahoe \& Pecht, 2003).

Although most of the outsourcing efforts made so far have been by big businesses, this dominance is starting to change in that smaller firms are also moving in the same direction in order to realize the benefits of outsourcing (McCracken, 2002). Some companies view outsourcing as a fast track system for penetrating new regions rather than a trend for the future (McCracken, 2002). Still others view outsourcing as a way to increase concentration on core-competencies, thus making it a more long-term approach (Bender, 1999; Corbett, 1996; Drezner, 2004; Engardio, Bernstein, \& Kriplani., 2003; Farrell \& Rosenfeld, 2005; Hoffman \& Tibodeau, 2003).

Most of the criticism concerning outsourcing has been primarily in the areas of changing employment patterns, globalization of the labor force, and its effect on individuals and organizations (Klass, McClendon, \& Gainey, 2001; Dobbs, 2004). Among the main causes considered to be the reason for job losses in manufacturing is increased productivity (Stonecipher, 2004). Outsourcing, by increasing productivity, may result in downsizing (Outlay \& Ranganathan 2005). Many US companies like Harley-Davidson, Dell, and Avago Technologies have announced that they will reduce their workforce as part of their outsourcing program.

However, the consequences of outsourcing are not limited to unemployment and the loss of capital (CNN Money, 2004). It can also result in the deterioration of morale among employees, (Engardio, 2006; Kennedy, Holt, Ward, \& Rehg, 2002). Displaced, unemployed workers have higher rates of child and spousal abuse, alcoholism, bankruptcy, divorce, etc (Dobbs, 2004; Jasper, 2003; Engardio, 2006; Weidenbaum, 2004). 
Most recent studies have focused on either the human aspects or the financial aspects of outsourcing but not on both aspects at the same time. Therefore, we find it necessary to conduct a longitudinal and experimental investigation into the effects of outsourcing strategies on participants' attitudes (the human aspects) as well as job performance (the financial aspects) of the program. In addition, there is a need to assess managerial opinion as to the value of the program for enhancing performance in both the short and long run. This topic deals directly with corporate strategy and is current and relevant for both employers and employees and has farreaching implications that have not been fully considered in the past.

\section{Literature Review and Research Framework}

Drawing on research findings, this study attempts to pull from theoretical literature to address the diverse perspectives on outsourcing strategies, performance measurements, and impacts. Measuring both the financial as well as the human aspects of outsourcing represents an area in which scholars have devoted some time in the past. This study addresses, in a meaningful and a practical way, the strengths of such research tradition.

Several researchers have focused on developing a theoretical framework for outsourcing (Geyskens, Steenkamp, \& Kumar, 2006; Griffiths, 2001; Charara, 2004; Narasimhan \& Jayaram, 1998). For instance, Bolumole, Frankel, and Nasland (2007) developed a framework which was based on the transaction cost-based perspective which considers outsourcing as a way by which organizations use external parties in order to reduce internal transaction and production costs.

On the other hand, Kumar and Eickhoff (2006) suggest that major drivers to outsourcing activities such as reduced labor cost are often overstated relative to others risks and issues such as intellectual property protection, quality, and supplier capabilities. When looking to outsource, an organization should be careful not to farm out work related to the core competencies of the firm. Geyskens, et al. (2006) evaluated transaction cost-based empirical research on organizational boundary (make, buy, or ally) decisions. They found strong support for the theory for both make versus buy and ally versus buy decisions. On the other hand, Moses and Ahlstrom (2008) clarified how make or buy decision processes develop overtime and how they cannot be seen as a one-time implementation but rather as a process that needs both structure and flexibility.

Other researchers have focused on successful implementation of outsourcing strategy which has been credited with helping to cut cost, increase capacity, 
improve quality, increase profitability, productivity, and improve financial performance and growth (Lau \& Hurley, 1997; Corbett, 1999; Crane, 1999; Jasper, 2003; Bartlett, 2004; Farrell, 2004; Drezner, 2004). Narasimhan and Jayaram (1998) focus on the notion that an integrated Supply Chain involves aligning sourcing decision in order to achieve manufacturing goals of responding favorably to needs of the customers. Outsourcing is often used by firms to pursue quality, costs, flexibility, and dependability objectives.

On the other hand, the outsourcing trend affects employees through the loss of fixed-employment opportunities and results in an increasing number of part-time and contract workers typically earning less pay than permanent workers and without health, life, short- and long-term disability, and retirement benefits (Charara, 2004; Crolius, 2006). It also implies a gradual structural change whereby a significant part of the workforce will be made up of part-time, temporary, freelance, or independent contractors (Klass, et al., 2001; Khan, 2004). Many researchers argue that the overall economic benefits of outsourcing are at the expense of the individual workers (Charara, 2004; Dobbs, 2004). Outsourcing usually has an impact on the organized labor by intimidating the labor force, as employees are threatened by the prospect of jobs moving overseas and are not enthusiastic about unionizing (Lazes \& Savage, 2000).

Kennedy, et al. (2002) viewed outsourcing in general, as a negative change, which therefore would create higher levels of dissatisfaction and increased likelihood of leaving their positions. Another study conducted by Walsh and Deery (2006) examined the effect of an outsourcing strategy on those who become employed as a result of that strategy. They found that the outsourcing contract created minimal job security for the new employees because the organization was not committed to these employees beyond the three-year contract. The study also found very limited opportunities for training and development, as well as promotions.

Outsourcing entails dramatic changes in the nature of work, control, and organizational design (Lever, 1997; Klass, et al., 2001; Engardio, et al., 2003). The outsourcing process usually results in the loss of productivity. Such lower productivity can exasperate an already unacceptable performance level and inspire additional outsourcing (Lever, 1997; Venkatraman, 2004; Roberts, 2005). As the outsourcing strategy continues, employees begin to feel insignificant and level of participation in their respective work groups gradually declines. This might cause an increase level of anxiety and stress (Kennedy, et al., 2002). Other empirical studies have shown that dissatisfied workers, after the implementation of outsourcing strategy, are more likely to leave the organization than their satisfied colleagues are (Spector, 1997; Charara, 2004). 
The reaction of the employees who participate in the outsourcing program should also be taken into consideration. Survivor syndrome, as defined in HR FOCUS Aug2009, "refers to a marked decrease in motivation, engagement, and productivity of employees that remain at the company as a result of downsizing and workforce reductions. It entails a series of complex psychological processes and subsequent behavioral responses." Feelings of fear, anger, grief, guilt, insecurity, unfairness, depression, reduced risk taking, and motivation are expressions of survival syndrome. Besides, "survivors" are expected to bring result soon, cover the extra work, and come up with new ideas (Baruch \& Hind, 1999; HR FOCUS, 2009; Kiplinger, 2009). This additional pressure may lead to high turnover.

Employees will be affected from the unilateral "violation of Psychological contract", which is the unwritten agreement between the employer and the employee in which the employer offers job security and stability at the exchange for loyalty and commitment (Sahdev, 2004, Baruch \& Hind, 1999). Unless this situation is addressed immediately with an effective retention strategy, it will bring additional loss of productivity, confusion, and stress. (Wood, 2009; HR FOCUS, 2009; Sahdev, 2004, Baruch \& Hind, 1999).

Corporate outsourcing - restructuring, downsizing and rightsizing - what do these terms represent? According to the experts on Wall Street, these terms are euphemisms for management's recognition that it must lay off individuals (Kiplinger, 2009; Outlay \& Ranganathan, 2005; Mol, 2007). It has been estimated that at current rates, $50 \%$ of U.S. manufacturing activities may be outsourced to firms in 28 emerging or developing countries by 2015 . Additionally, outsourcing of services by U.S. firms is expected to lead to the migration of four million jobs to these nations by $2008-2010$ (Fitzpatrick \& Dilullo, 2007).

\section{More In-Depth Studies are Needed}

Despite the frequency with which outsourcing strategies have been adopted in work organizations, (Corbett, 2002; Reaser, 2004; Engardio, et al., 2003; Dobbs, 2004) there is a paucity of knowledge generated by independent evaluators using rigorous methods as to the impact of participation in an outsourcing strategy on employee attitudes and behaviors. Most available studies are limited to testimonials from managers and consultants who have implemented outsourcing strategies (Cassale, 1996; Corbett, 1996; Crane, 1999; Bender, 1999; Farrell \& Rosenfeld, 2005; Fraser, Kane, \& Schaefer, 2004; Feulner, 2004; Irwin, 2004). The central theme that runs through most of the studies on outsourcing strategies reflects a common 
belief that they generally improve organizational effectiveness or may have a severe impact on organized labor force and deterioration of morale among employees (Drezner, 2004; Florida, 2004; Jasper, 2003; Engardio, et al., 2003; Charara, 2004). Consequently, more information is needed to understand issues, directions, and implications of outsourcing strategies to both employers and employees and to study the effects of outsourcing strategies on participants attitudes (the human aspects) as well as job performance (the financial aspects) of the program.

\section{Research Framework}

The preceding discussion provides a basis to the research framework. It identifies several outsourcing measurement variables including cost, dependability, flexibility, quality and variety of products and services, quality of work-life indicators, suppliers' capability and performances. The casual linkages among these variables are assumed to influence organizational performance and customer responsiveness. The research model views these variables as important elements of effective outsourcing strategy and linked to organizational performance as shown in Figure 1.

Both the financial and the human aspects of outsourcing and findings from organizational behavior knowledge suggest six research hypotheses to guide an investigation of the impact of outsourcing strategies on participant's attitudes and job performance:

Hypothesis 1: Participants in outsourcing strategies will report lower levels of job satisfaction than will non-participants.

Hypothesis 2: Participants in outsourcing strategies will report lower scores in quality of work life measures than will non-participants.

Hypothesis 3: Participants in outsourcing strategies will report lower levels of organizational commitment than will non-participants.

Hypothesis 4: Participants in outsourcing strategies will report higher intensions to quit than will non-participants.

Hypothesis 5: Managers will report positive assessments of the contributions of outsourcing strategies to organizational performance.

Hypothesis 6: Outsourcing strategies will provide measurable financial returns to the sponsoring organization.

These hypotheses are tested in a longitudinal and experimental field study that compares changes in perceptions of quality of work life attitudes and job per- 
formance, for participants and non-participants in an outsourcing program in an industrial setting.

\section{Figure 1}

\section{Conceptual Model of Strategic Outsourcing Performance Measures}

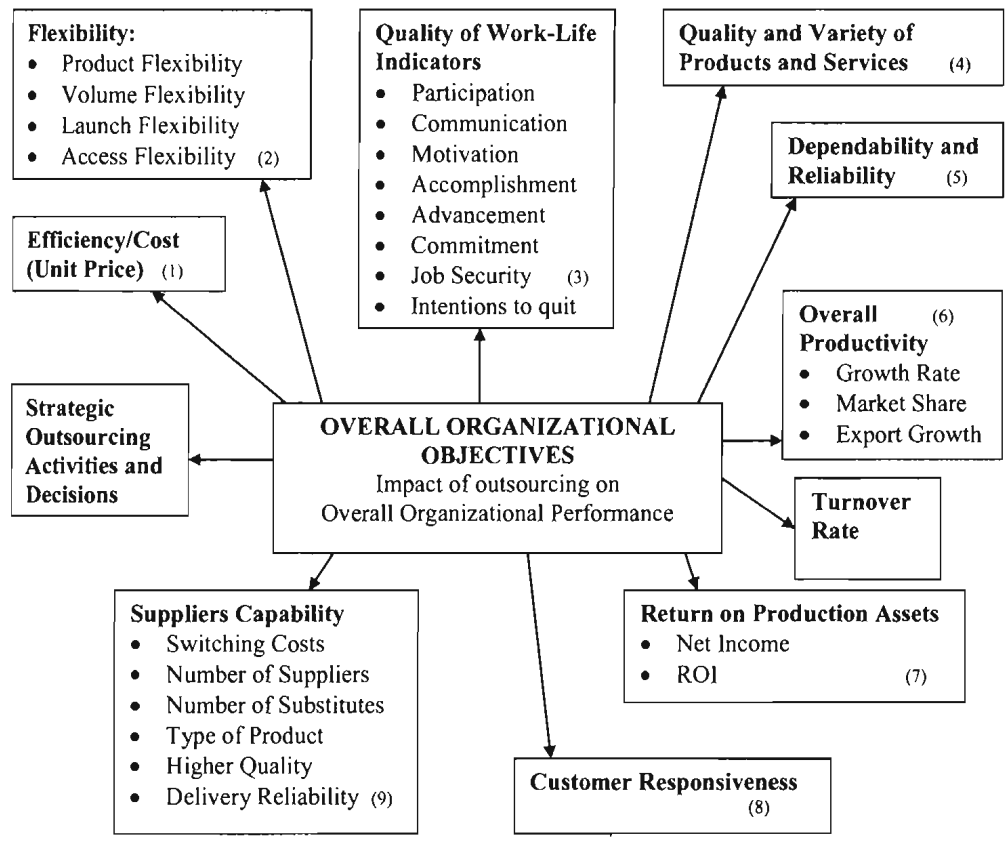

ladapted from Narasimhan \& Jayaram, 1998; Kennedy, et al., 2002; Judge \& Dooley, 2005; Geyskens, et al., 2006; Kumar \& Eickhoff, 2006; Bolumote, et al., 2007.]

$1-0.55,2-0.54,3-0.36,4-0.35,5-0.42,6-0.62,7-0.65,8-0.52,9-0.64$. These numbers refer to the results of the multiple regression variations between performance and several variables in this study.

\section{Methodology}

\section{Research Sites and Participants}

This research was conducted in two manufacturing plants of a large, diversified, non-unionized, multi-divisional corporation located in an urban area in the 
Midwestern United States. The company has a total of four assembly plants located in three states. The two plants used for this study were located in the same state and produced a variety of electronic components, measuring and control devices, control panels, and auto parts components. Plant "A" provided an experimental group of individuals who were already involved in several types of outsourcing functions (e.g., upgrading their information technology capabilities, managing their logistics and their supply chain, administrating standard employee benefits, outsourcing some electronic components, transfer of staff and/or production functions to a more efficient location, and removing or adding new product lines) and who participated in implementing the outsourcing program in their plan. Plant " $B$ " within the same company provided a matched comparison group of individuals who did not adopt outsourcing programs for their plant and indicated that they did not anticipate wanting to seek such an adoption in the foreseeable future due to internal environmental issues and highly effective relationships between labor and management, which include participation of employees in decision making and having weekly meetings between labor and management.

The experimental plant " $\mathrm{A}$ " had a workforce of 1,600 employees at the time the study was planned, but the workforce was reduced to 896 employees due to outsourcing activities such as logistics and supply chain, some electronic components, transfer of staff to different locations and outsourcing employee benefits. The comparison plant " $\mathrm{B}$ " employed 1,500 employees at the beginning of the study, and there was little change in the total number of employees during the same period of the study. Both plants produced the same type of products, employed the same technologies, and had similar work forces. The participants in the outsourcing program and non-participants were comparable on most areas. Both plants were in financial distress due to high operation costs. The participants in the outsourcing program included employees who stayed with the company and/or worked with those employees transferred from other locations within the company due to outsourcing decisions or laid off, were also known as "survivors."

During the time of this study, the company (included both Plant A and Plant B) was in financial distress primarily due to high operation costs, low productivity, high reject rates, little export sales, and intensive foreign competition. In response to these problems and with an eagerness to increase export sales and cut cost, a new training and outsourcing programs were introduced in plant "A." The new program in plant " $\mathrm{A}$ " was actively keeping abreast of new trends in cost cutting techniques and practices, especially those associated with outsourcing programs and to some degree cost-cutting techniques. The outsourcing program was one technique that at- 
tracted the attention of top managers because many industries are finding outsourcing strategies may be directly related to future survival.

A consulting group was invited to train managers and employees at all levels of the organization and assist in the implementation of the outsourcing program. The consulting group made it clear from the beginning that success depended to a large degree on the cooperation and participation of all job holders and support from senior and middle management.

\section{Measures of Quality of Work Life and Organizational Commitment Perceptions}

A questionnaire, archival data, and follow-up interviews were used to accomplish this study. The questionnaire was designed to tap a wide range of quality-of-work life facets, with measures derived from the Michigan Organizational Assessment Package and Organizational Commitment Measures Package. The Michigan instrument and Organizational Commitment Measures have been shown to have acceptable levels of reliability and validity across a variety of settings (Lawler, 1975; Marks, Mirvis, Hacket, \& Grady, 1986; Tett \& Meyer, 1993). Responses were reported on seven-point scales, ranging from one (low) to seven (high) for all measures. Included in the questionnaire were measures of each of the researched quality-of-work life areas. Measures of participation and communication available from the questionnaire was a self-report of the frequency with which suggestions are offered at work, an item assessing satisfaction with opportunities to take part in decisions, scales of work team communication. Measures of organizational commitment were measured with the 15-item scale. Responses were reported on sevenpoint scales anchored by strongly agree and strongly disagree.

The population sampled included all full-time employees in both plants: production workers, machine operators, supervisors, support staff in information technology, supply chain, human resources and managers from different functional areas, and senior managers. There were two surveys to accomplish this study. One survey was conducted at the research sites just prior to the implementation of the outsourcing program to assess employee attitudes and quality-of-work life facets in general in each plant. Questionnaires were returned by 548 employees at plant "A" generating 34\% participation rate. At plant "B," 540 employees returned the questionnaire, generating a $36 \%$ participation rate. A second survey was conducted 18 months after the program had begun to assess any changes on employee perceptions. 362 employees at plant " $\mathrm{A}$ " and 610 employees at plant " $\mathrm{B}$ " returned question- 
naires generating a $40 \%$ participation rate for both plants. A demographic description of the survey respondents was compared to that of the whole population at both plants. This way, it could be determined if the actual sample was representative of the population. The results of that comparison indicated that the demographic characteristics of both the sample and the whole population at both plants were similar in all aspects. The sample included $60 \%$ males and $40 \%$ females, who had a high school education or more and earned an average income of $\$ 24,000$ a year.

Several variables were identified for the purpose of this study including independent elements such as cost, flexibility, dependability, quality, outsourcing activities, and suppliers power. Other variables focused on dependent elements including organizational performance, quality of work-life dimensions, and customer satisfaction and outsourcing dimensions to enhance their credibility. The reliability of measuring scales used in this study was estimated at 0.73 , as determined by applying Cronbach's alpha formula to mean inter-item correlation. Although the magnitude of a reliable Cronbach's alpha is addressed differently by researchers, a value greater than 0.70 is typically considerably good criterion for adequate scale reliability (Cronbach, 1951; Nunnally, 1987).

\section{Measures of Organization Performance - Actual Data}

Actual organizational data from the surveyed firm (productivity, quality, flexibility, and other performance indicators) were used to assess the impact of outsourcing strategies on organizational performance. Productivity was measured by ratio of output produced to resources used. Four productivity measures were available from organization records:

- Efficiency rate (number of products produced within quality specification divided by industrial engineering output rate) (Beamon, 1999).

- System efficiency level includes personal requirement, equipment utilization energy usage and cost (Chase, Nicholas, \& Jacobs, 2000).

- Flexibility measures can measure a system's ability to accommodate volume and schedule functions from supplier, manufacturers, and customers. Flexibility is vital to the success of the outsourcing program in an uncertain environment (Narasimhan \& Jayaram, 1998).

- Overall productivity (total hours earned [number of actual pieces of product produced divided by number of pieces of product expected to be produced] divided by total hours paid) (Marks, et al., 1986; Mott, 1972). 
Additionally, records of quality and customer complaints were collected from an internal quality audit and the number of defects per finished product per 1,000 units was added and averaged per six months (Crosby, 1979). Furthermore, records of return on trading assets and other performance indicators were collected from sales and financial statements and were reported in percentage to total sales (Beamon, 1999). Data for each of the performance measures were collected for a 24-month period, ranging from six months prior to the adoption of outsourcing program to 18 months after the program began.

This length of measurement provided adequate time to assess the impact of outsourcing program on employee productivity, quality of their products, and return on trading assets. Average rates were then computed for six-month intervals and compared before and after the program began. Period 1 represents the average rate for the six months prior to the program implementation, Period 2 is the average rate for the first six months after the program was operational, Period 3 is the average rate for months $7-12$, and Period 4 is the average rate for months $13-18$.

\section{Managerial Assessment}

In-depth and structural interviews were conducted with twenty managers and supervisors including the plant managers, human resources manager, several operations managers, frontline supervisors, and controller in this manufacturing facility. The purpose of the interviews was to obtain a deeper perspective of the effect of outsourcing program on productivity, cost, flexibility, customer responsiveness, quality, employee performance and turnover rate as well as to assess the effectiveness of the program relative to its costs. Furthermore, the interviews were used to rule out other possible explanations for changes in employee performance in the plant. During the interviews, the managers and supervisors responded to a seven item questionnaire.

Another interview was conducted with five senior managers of the company to assess the effectiveness of the outsourcing program and to discuss how the company might be able to salvage employees who had difficulty adapting to outsourcing strategies. Another issue discussed with senior managers was how to manage the "survival syndrome" and increase employees motivation and engagement as a result of changes in the organization. 


\section{Results and Analysis of Quality of Work Life Perceptions}

To measure the quality-of-work life and organizational commitment perceptions, several statistical tests were employed to evaluate the research hypothesis, including univariate F-test across time periods for each dependent variable for differences between experimental and comparison groups and multiple regression analysis. Table I presents the mean scores of quality-of-work life and organizational commitment perception measures for participants and non-participants before and after implementation of the outsourcing program. There were differences over time for each variable for the participant groups at plant "A" but not for the non-participant groups at plant "B." For example, there was a difference between the mean values for suggestions offered within the participant groups across the three time periods, but there were little differences between the mean values for the same variable within the non-participant groups.

There were also some differences at Periods 2, 3 and 4 between the two groups in mean values for suggestions offered, participation in decision making, work group communication, meaning, challenge accomplishment, advancement, and organizational commitment. Table 1 summarizes the results, which show a clear pattern of changes in the means. The greatest and most consistent changes were between Period 1 and Period 4, when all quality-of-work life and organizational commitment dimensions in the participant groups decreased significantly. By Period 4, however, all dimensions had decreased to a level significantly different from Period 2. The overall preparticipation F-value (1.10) was not significant, but the post participation in the outsourcing program F-value (3.27) was significant at the .05 level. The $\mathrm{F}$-values were also significantly different from each other at the .01 level. 
Table 1

Results of Univariate F-Tests for Differences Between Participants and Nonparticipants in the Outsourcing Program

\begin{tabular}{|c|c|c|c|c|c|c|}
\hline $\begin{array}{l}\text { Dependent Variables of } \\
\text { Quality-of-work Life }\end{array}$ & $\begin{array}{l}\text { Period } 1 \\
\text { Prior to }\end{array}$ & $\begin{array}{l}\text { Period } 2 \\
\text { First } 6\end{array}$ & $\begin{array}{l}\text { Period } 3 \\
\text { For months } F\end{array}$ & $\begin{array}{l}\text { Period } 4 \\
\text { For months }\end{array}$ & $\begin{array}{l}\text { Change } \\
\text { Period } 1\end{array}$ & \\
\hline Dimensions & Outsourcing & months & $7-12$ & $13-18$ & - Period 4 & F-value \\
\hline \multicolumn{7}{|l|}{ Suggestions Offered } \\
\hline Participants & 2.90 & 1.30 & 1.20 & 1.20 & 1.20 & $3.60^{*}$ \\
\hline Nonparticipants & 2.92 & 2.90 & 2.94 & 2.92 & 0.00 & 4.02 \\
\hline \multicolumn{7}{|c|}{ Participation in Decision Making } \\
\hline Participants & 3.88 & 2.30 & 2.20 & 2.20 & 1.50 & $4.28^{\star \star}$ \\
\hline Nonparticipants & 3.87 & 3.86 & 3.88 & 3.88 & 0.05 & 2.70 \\
\hline \multicolumn{7}{|c|}{ Work Group Communication } \\
\hline Participants & 3.20 & 2.15 & 2.10 & 2.05 & 1.08 & $4.90^{\star}$ \\
\hline Nonparticipants & 3.25 & 3.20 & 3.25 & 3.30 & 0.00 & $2.22^{\star}$ \\
\hline \multicolumn{7}{|c|}{ Organization Communication } \\
\hline Participants & 2.60 & 1.85 & 1.60 & 1.66 & 0.83 & $4.92^{\star \star}$ \\
\hline Nonparticipants & 2.64 & 2.60 & 2.65 & 2.65 & 0.01 & 3.80 \\
\hline \multicolumn{7}{|l|}{ Meaning } \\
\hline Participants & 3.77 & 2.10 & 2.05 & 1.95 & 1.68 & $5.25^{\star *}$ \\
\hline Nonparticipants & 3.80 & 3.80 & 3.80 & 3.80 & 0.00 & 2.06 \\
\hline \multicolumn{7}{|l|}{ Challenge } \\
\hline Participants & 2.88 & 1.85 & 1.90 & 1.77 & 1.01 & $5.40^{* *}$ \\
\hline Nonparticipants & 2.90 & 2.90 & 2.85 & 2.95 & 0.00 & 3.68 \\
\hline \multicolumn{7}{|l|}{ Personal Responsibility } \\
\hline Participants & 2.80 & 1.75 & 1.45 & 1.60 & 1.15 & $4.30^{\star \star}$ \\
\hline Nonparticipants & 2.84 & 2.80 & 2.88 & 2.85 & 0.00 & 3.80 \\
\hline \multicolumn{7}{|l|}{ Accomplishment } \\
\hline Participants & 3.66 & 1.70 & 1.60 & 1.40 & 1.50 & $4.40^{\star \star}$ \\
\hline Nonparticipants & 3.70 & 3.65 & 3.60 & 3.75 & 0.00 & 3.30 \\
\hline \multicolumn{7}{|l|}{ Advancement } \\
\hline Participants & 2.78 & 1.94 & 1.90 & 1.70 & 0.85 & $4.40^{\star \star}$ \\
\hline Nonparticipants & 2.74 & 2.70 & 2.70 & 2.75 & 0.00 & 3.20 \\
\hline \multicolumn{7}{|c|}{ Organizational Commitment } \\
\hline Participants & 3.20 & 1.60 & 1.40 & 1.30 & 1.40 & $4.60^{\star}$ \\
\hline Nonparticipants & 3.20 & 3.20 & 3.25 & 3.28 & 0.04 & $4.90^{\star}$ \\
\hline
\end{tabular}

${ }^{*} p<.05 ;{ }^{* *} P<.01$

Further analysis of the relationship between the outsourcing system, qualityof-work life, and organizational commitment was done with the use of multiple regression analysis. This analysis determines the proportion of variance in qualityof-work life and organizational commitment scores explained by the outsourcing program scores. The principle behind an outsourcing program is farming out cer- 
tain activities or processes, usually performed by company employees, to external contractors specializing in such activities or processes. Functions, or performance indicators, were used to measure the independent variables in this study as defined in the questionnaire.

Table 2

Multiple Regression of the Relationships Between Participation in the Outsourcing Program and Perceptions of Quality-of-Work Life and Organizational Commitment

\begin{tabular}{lccccc}
\hline Independent Variable & & & & & \\
\hline & $\begin{array}{c}\text { Dependent } \\
\text { Variable } \\
\text { at Period } 1^{*}\end{array}$ & $\begin{array}{c}\text { Dependent } \\
\text { Variable } \\
\text { at Period } 4^{*}\end{array}$ & $\begin{array}{c}\text { F-Ratio } \\
\text { Average }\end{array}$ \\
\hline Dependent Variables & $r$ & $r^{2}$ & $r$ & $r^{2}$ & \\
\hline 1. Participation in decision/making implementation & .0262 & .2212 & -.1426 & -.1238 & 4.10 \\
2. Suggestion offered/implemented & .0282 & .2444 & -.1566 & -.1440 & 3.38 \\
3. Work group communication & .2640 & .2630 & -.1678 & -.1470 & 3.10 \\
4. Organization communication & .2925 & .2887 & -.1830 & -.1640 & 4.40 \\
5. Job meaningfulness & .2510 & .2240 & -.1844 & -.1630 & 3.38 \\
6. Job challenge/motivation & .2870 & .2618 & -.1537 & -.1420 & 4.22 \\
7. Personal responsibility for work & .2370 & .2070 & -.1487 & -.1222 & 3.47 \\
8. Perceived opportunities for accomplishment & .2290 & .2062 & -.1588 & -.1392 & 3.77 \\
9. Perceived opportunities for advancement & .2380 & .2118 & -.1820 & -.1677 & 3.48 \\
10. Perceived organizational commitment & .2540 & .2250 & -.1850 & -.1720 & 3.90 \\
11. Intentions to quit & .1488 & .1230 & -.3880 & -.3620 & 3.45 \\
\hline
\end{tabular}

All $p<.01$

*Period 1 prior to the implementation of the outsourcing program and Period 4 after the programis inception.

- The negative sign indicates negative variations or relationships.

Table 2 presents the results, of this analysis, which indicates a negative relationship between measures of the outsourcing program, quality-of-work life, and organizational commitment as reflected in the multiple regression rations $\left(r^{2}\right)$. The results show that more than $-12.38 \%$ of the variation in participation in decision making, $-14.40 \%$ of the variation in suggestion offered, $-14.70 \%$ of the variation in group communication, $-16.40 \%$ of the variation in organization communication, $-16.30 \%$ of the variation in job meaningfulness, $-14.20 \%$ of the variation in job challenge, $-13.92 \%$ of the variation in perceived opportunities for accomplishment, $-16.77 \%$ of the variation in perceived opportunities for advancement, and more than 
$-17.20 \%$ of the variation in the perceived organizational commitment are explained by linear regression on the outsourcing program dimensions. The F-ratios indicate that these linear associations are statistically significant at the .01 level. These findings, as well as the univariate F-tests across time periods, provide evidence to substantiate the research hypotheses ( 1 to 4 ), and coincide with the claims of many academicians and authors that some of the consequences of job outsourcing not only culminate with unemployment but also the loss of capital. It can result in the deterioration of morale among employees, decrease quality-of-work life, and organizational commitment attitudes among employees as a consequence of outsourcing decision (Engardio, et al., 2003; Jasper, 2003; Kennedy, et al., 2002, Charara, 2004; Crolius, 2006; Dobbs, 2004).

\section{Analysis of Organizational Performance Impacts}

Table 3 presents the average six month rates for the performance measures beginning six months prior to the adoption of the outsourcing program until 18 months after the program began. For each measure, the average percentage of production efficiency rate was $44 \%$, system efficiency rate was $56 \%$, overall productivity average rate was $64 \%$, the average number of defects per 1,000 units was $222 \%$, system flexibility rate was $50 \%$, net income average rate was $4 \%$, return on investment average rate was $2 \%$, market share average rate was $2 \%$, export growth average rate was $0 \%$, and turnover rate was $18 \%$ before the implementation of the outsourcing program. Table 3 also presents the average rates 18 months after the program began. For each measure, the average rate for the two periods was different. As can be seen in the table, some degree of improvement was shown in each area after the program began. All except for turnover rate was increased, which means more employees are leaving or have the intent to leave the company due to outsourcing activities or feeling job insecurity.

At the same time, there were negative or no significant differences for performance dimensions for the comparison group in plant " $B$ " that did not adopt the outsourcing program in their plant as seen also in Table 4. Furthermore, the performance measures document a negative result for the non-participants group in areas such as system flexibility and efficiency and showed no improvement in areas such as net income, return on investment, market share, or expert growth. 
Table 3

Data From Organizational Records

\begin{tabular}{|c|c|c|c|c|c|c|}
\hline \multirow[b]{2}{*}{$\begin{array}{l}\text { Performance } \\
\text { Dimensions in (\%) }\end{array}$} & $\begin{array}{l}\text { Before Program } \\
\text { Implementation }\end{array}$ & \multicolumn{5}{|c|}{$\begin{array}{l}\text { After Outsourcing Program Adoption in } \\
\text { Plant "A" after Program Implementation }\end{array}$} \\
\hline & $\begin{array}{l}\text { PRD } 1 \\
\text { Avg \% }\end{array}$ & $\begin{array}{l}\text { PRD } 2 \\
\text { Avg \% }\end{array}$ & $\begin{array}{l}\text { PRD } 3 \\
\text { Avg \% }\end{array}$ & $\begin{array}{l}\text { PRD } 4 \\
\text { Avg \% }\end{array}$ & $\begin{array}{l}\text { PRD 2-4 } \\
\text { Avg } \%\end{array}$ & $\begin{array}{l}\text { Prd 1- } \\
\text { Avg } 4 \\
\text { Avg \% }\end{array}$ \\
\hline Production efficiency rate & 44 & 52 & 58 & 58 & 56 & 27 inc. \\
\hline System efficiency level & 56 & 58 & 60 & 62 & 60 & 7 inc. \\
\hline $\begin{array}{l}\text { Overall productivity rate } \\
\text { Quality given in number of } \\
\text { defects per } 1,000 \text { units }\end{array}$ & 222 & 180 & 171 & 170 & 174 & 21 inc. \\
\hline System flexibility & 50 & 54 & 58 & 54 & 55 & 10 inc. \\
\hline \multicolumn{7}{|c|}{ Other Performance Indicators } \\
\hline Net income & 4 & 5 & 6 & 8 & 6.3 & 57 inc. \\
\hline Return on investment & 2 & 3 & 3 & 4 & 3.3 & $65 \mathrm{inc}$. \\
\hline Market share & 2 & 2 & 4 & 4 & 3.3 & 65 inc. \\
\hline Export growth & 0 & & & & 4 & $100 \mathrm{inc}$. \\
\hline Turnover rate & 18 & 39 & 46 & 48 & 44 & 144 inc. \\
\hline
\end{tabular}

Table 4

Data From Organizational Records

\begin{tabular}{|c|c|c|c|c|c|}
\hline \multirow{3}{*}{$\begin{array}{l}\text { Performance } \\
\text { Dimensions in (\%) } \\
\text { Production efficiency rate }\end{array}$} & \multirow{3}{*}{$\begin{array}{c}\begin{array}{c}\text { Before } \\
\text { Program } \\
\text { Implementation }\end{array} \\
\text { PRD 1 } \\
\text { Avg \% } \\
44\end{array}$} & \multicolumn{4}{|c|}{$\begin{array}{l}\text { After Program Implementation } \\
\text { Avg \% of Increase or Decrease }\end{array}$} \\
\hline & & \multicolumn{2}{|c|}{$\begin{array}{l}\text { PRD 2-4 } \\
\text { Avg } \%\end{array}$} & \multicolumn{2}{|c|}{$\begin{array}{l}\text { PRD 2-4 } \\
\text { Avg } \%\end{array}$} \\
\hline & & 56 & 27 inc. & 48 & $7.6 \mathrm{dec}$. \\
\hline System efficiency level & 56 & 60 & 7 inc. & 52 & $14 \mathrm{dec}$ \\
\hline Overall productivity rate & 64 & 68 & $6 \mathrm{inc}$. & 62 & $6 \mathrm{dec}$. \\
\hline $\begin{array}{l}\text { Quality given in number of } \\
\text { defects per } 1,000 \text { units }\end{array}$ & 222 & 174 & $21 \mathrm{dec}$ & 190 & $5.5 \mathrm{inc}$ \\
\hline System flexibility & 50 & 55 & 10 inc. & 52 & $3.8 \mathrm{dec}$ \\
\hline \multicolumn{6}{|c|}{ Other Performance Indicators } \\
\hline Net income & 6 & 6.3 & 57 inc. & 4 & 20 dec. \\
\hline Return on Investment & 2 & 3.3 & 65 inc. & 2.2 & $2.6 \mathrm{dec}$ \\
\hline Market share & 2 & 3.3 & 65 inc. & 2 & 0 \\
\hline Export growth & 0 & 4 & 100 inc. & 0 & 0 \\
\hline Turnover rate & 18 & 44 & 144 inc. & 42 & $8.6 \mathrm{dec}$. \\
\hline
\end{tabular}




\section{Relationship between Outsourcing Decisions and Performance}

The relationship between outsourcing decisions and supplier power and organizational performance was examined through the use of multiple regression analysis. Table 5 presents the results of this analysis. These results point to a positive relationship between measures of outsourcing decision and supplier power and the organizational performance, as reflected in the multiple regression ratios. The results show the variations (55\% in cost (unit price), $35 \%$ in quality, $54 \%$ in flexibility, $42 \%$ in dependability, and $64 \%$ in overall performance) as explained by linear regression for the outsourcing decisions and supplier power dimensions. The F-ratios indicate that these linear associations are statistically significant at $\mathrm{P}<.01$.

The causal link between outsourcing decision and organizational performance was statistically significant, confirming prior expectations and complementing previous studies (Walsh \& Deery, 2006; Chase, et al., 2000). The study points to positive impact of outsourcing decisions and supplier power on the organizational performance in terms of low cost, high quality, flexibility, and dependability, thus improving competitiveness and profitability (Narasimhan \& Jayasam., 1998; Chase, et al., 2000; Vickery, Jayaram, Droge, \& Calatone, 2003; Roberts, 2006). These findings provided positive responses to hypotheses (5 and 6 ) of the study.

\section{Table 5}

\section{Results of Regression Analysis for Outsourcing Decision and Supplier Power} and Organizational Performance

\begin{tabular}{lccc}
\hline $\begin{array}{l}\text { Dependent Variable Outsourcing } \\
\text { Decisions and Supplier Power }\end{array}$ & $\begin{array}{c}\text { Multiple } \\
\text { Regression }\end{array}$ & $\begin{array}{c}\text { Regression } \\
\text { Square }\left(\mathbf{R}^{2}\right)\end{array}$ & F-Ratio \\
\hline Cost (unit price) & 0.68 & 0.55 & 5.60 \\
Quality & 0.44 & 0.35 & 3.42 \\
Flexibility & 0.69 & 0.54 & 5.40 \\
Dependability & 0.56 & 0.42 & 4.75 \\
(1 to 5) Performance Dimensions & 0.79 & 0.64 & 9.64 \\
\hline
\end{tabular}

All $P<.01$

\section{Findings from Follow-up Interviews}

In the interviews, all twenty managers and supervisors including the plant controller expressed overwhelming support for the outsourcing program. They also claimed that the program was making a contribution to organizational productivity, quality of products, and export sales. However, the outsourcing program 
had negative effects on quality-of-work life dimensions and turnover rates in the plant "A."

The plant manager indicated that his plant gained 8,000 hours in the production areas due to reduced absenteeism. He claimed that the proportion of employee days missed dropped from $11 \%$ per year to less than $7 \%$ for the whole plant. The human resource manager, the operations manager, and the information system manager claimed the program to be a success in the areas of fill rate, on-time deliveries, reliable delivery, customer responsiveness, quality, customer service, and production costs. However, the outsourcing program had negative effects on quality of work-life dimensions such as job security among employees, and turnover rates in the plant. Most of the interviewed managers agreed that the consequences of outsourcing and job stress must be addressed directly. Employees must be encouraged to reengineer their jobs and make them more manageable. All employees must be treated fairly.

All twenty managers, engineers, supervisors, and the plant controller provided independent assessments of the effectiveness of the outsourcing program and expressed confidence in the program. They pointed to improvements in customer service and equipment performance and maintenance, including computer-internet, as well as online hardware and software components. These in-depth interviews also provide evidence to substantiate research hypothesis five (5), regarding managerial assessment of the contribution of the outsourcing program to organizational performance. Furthermore, they indicated that there were no other major changes in activities, technologies or incentives in their plant for the 18 months following the program initiation that could have accounted for the gains. They also remarked that there were no major shifts or changes related to the competitive environment within their region.

To make corporate outsourcing more effective in the future, most of the senior managers surveyed in this company suggested that their company should empower lower level employees with some of the corporation's decisions, taking advantage of potential opportunities overseas and establishing training, retaining and outplacement counseling programs. Furthermore, these senior managers indicated that managers and employees in plant " $B$ " were in financial distress and must adopt new cost cutting techniques and practices, especially those associated with outsourcing programs. For the effectiveness of operations, furloughs are preferable to layoffs. Generally speaking, a furlough is a temporary unpaid leave of absence during which an employee would not perform his or her usual and customary job duties. 


\section{Discussion}

The attitudinal results of this research found that outsourcing was a major change from the "normal" way of doing business. Statistical analysis indicated that involvement in the outsourcing program in this case was negatively related to perceived changes in satisfaction with opportunities, for participation at work, to accomplish something worthwhile at work, and enhancing opportunities and skills for advancement in the organization. Furthermore, participation in the outsourcing program was negatively related to perceived changes in communication throughout the organization, as well as job meaningfulness, challenge, and personal responsibility for work.

These findings, as well as the statistical analysis across time periods, provide evidence to substantiate the research hypotheses ( 1 to 4 ) regarding the impact of outsourcing decisions on job satisfaction, quality of work life, organizational commitment, and employees' intentions to quit the organization.

The overall preparticipation in the outsourcing program F-Value (1.10) was not significant, but the post participation in the program F-Value (3.27) was significant at the .05 level. It is therefore, appropriate to accept the research hypotheses $(1$ to 4$)$ in this study and to state with more than $95 \%$ confidence $(P<.05)$ that a negative relationship was found between outsourcing program, job satisfactions (Hypothesis 1), quality-of-work life (Hypothesis 2), organizational commitment, (Hypothesis 3) and higher turnover intentions (Hypothesis 4) as shown in the research Model Figure 1 in this study. These findings coincide with the claims of many academicians that implementation of outsourcing activities can increase job dissatisfaction, increase turnover rates, and decrease employee motivation and commitment (Kennedy, et al., 2002; Engardio, 2006; Charara, 2004). The results indicated that of the participants with negative views of outsourcing, almost sixty percent of the participants were more dissatisfied with their jobs and the work environment, and they were more likely to leave the company as soon as they find a more reliable work environment. Furthermore, outsourcing, specifically, has shown to evoke employee's fear of the unknown, anxiety over the future, nostalgia for the old days, and resentment over the loss of identity and job security.

A new "Psychological contract" is recommended to fill the gap created between employees and their employer. The contract will add more responsibility on workers' in terms of work load, additional time, creativity, team work at the exchange of greater payment, performance based reward, and training and development, which increases their employment opportunity (Sahdev, 2004, Baruch \& Hind, 1999). 
To manage the "Survival Syndrome" and increase workers' motivation and engagement, managers must work to improve the communication flow, encourage workers to participate in decision making, relate reward to performance, treat employec as individuals, build trust in leadership, and use other motivational methods (Woodruff, 1995, HR FOCUS, 2009).

The performance measures, however, document a positive impact of outsourcing activities on employee performance. Participants in the outsourcing program tended to increase the percentage of time spent on an actual production, produced a higher rate of products and increased export sales within Industrial Engineering Specifications. The link between these favorable changes and the outsourcing program were supported further in the follow-up interviews with key managers in the plant. All of those interviews indicated that the outsourcing program made a contribution to the organizational productivity, quality of products produced, and performance dimensions. These in-depth interviews and these findings as well as the statistical analysis across time periods provide evidence to substantiate the research hypotheses ( 5 and 6 ) regarding the impact of outsourcing decisions on performance dimensions (efficiency, productivity, quality, flexibility, and other performance indicators). The overall postparticipation in the outsourcing program F-ratios indicate that these liner associations are statistically significant at the .05 level. It is therefore appropriate to accept the hypotheses ( 5 and 6 ) in this study and to state with more than $95 \%$ confidence $(\mathrm{P}<.05)$ that a positive relationship was found between outsourcing program and performance dimensions as shown in the Research Model Figure 1. These changes can, at least in part, be attributable to the outsourcing activities. Prior to the outsourcing program, for example, machine operators would wait for a set-up person to make a needed adjustment in a machine or other equipment. From outsourcing program discussions, some employees learned how to make these adjustments and increased the percentage of time spend on actual production. Although the overall performance increased for the outsourcing program participants, little changes were found in the nonparticipant group, Plant $\mathrm{B}$. This may be a contamination effect as a result of the outsourcing activities, where outsourcing has shown to evoke employees' fear of the unknown, loss of jobs, and uncertainty over the future. People who had jobs may have incrcased their attendance and productivity at work in an effort to help insure keeping their jobs (Charara, 2004; Kennedy, 2002; Engardio, 2006). 


\section{Limitations}

There are obvious limitations to the perceptual and self-reported data collected in this study, as well as with correlation analysis of such data. Interview responses from the key managers could be biased since the program was one that they may have personally requested or supported. In addition to these limitations, a training program was conducted in plant " $\mathrm{A}$ " and plant " $\mathrm{B}$." The training was directed to increase efficiency and improve quality which may have improved organizational performance. In this case, it was very hard, if not impossible, to distinguish between the effects of their outsourcing program from the training program in plant "A." However, significant observed performance improvements were reported in plant "A" not plant "B." In addition, the data is collected from only one firm, which means the results cannot be generalized to other firms.

Despite these limitations, this exploratory empirical investigation provides tentative avenues for increasing the probability of success of outsourcing projects and identifies areas that need further research. This study identified key dimensions of an outsourcing strategy and organizational performance dimensions in one firm in a manufacturing setting. Nevertheless, further work is needed in a variety or industry settings to confirm a global outsourcing-supply chain management-performance linkages and should incorporate suppliers, customers, and other shareholders into the measurement and analysis process.

\section{Conclusion and Implications}

Over the past decade, outsourcing and restructuring became the predominant reaction to global competition, low productivity, and increasing labor costs in corporate America. Recessionary pressures have forced many businesses, including this corporation to maintain efficiency and reduced personnel in an attempt to retain bottom line and to increase profitability.

Outsourcing strategy has been prescribed as an important tool for attaining and maintaining a competitive advantage. In addition, outsourcing is growing in appeal to organizations because of the cost savings achieved in executing operations. It is also seen as a means to draw on the expertise and resources of a partner to shorten time to market, increase customer satisfaction, and to exploit fast-changing technology.

At the same time, outsourcing has created two kinds of victims: workers who have lost their jobs and suffered the hardship of trying to find new employment, and employees who have survived the outsourcing cuts but suffered the physical and 
psychological burdens of a downsized environment. To make corporate outsourcing more effective in the future, most of the senior managers surveyed in this company suggested that their company should consider adapting measures to prevent these negative developments. These efforts include not bulking up on layers of management in times of expansion, empowering lower level employees with some of the corporation's decisions, taking advantage of potential opportunities overseas, and establishing training, retaining and outplacement counseling programs. The senior management of this company indicated that they are willing and ready to combine the advantages of a cost effective strategy such as the outsourcing program in plant " $A$ " and also harness the engine of full employee motivation and commitment as the case in plant "B." Managers must work to improve the communication flow, encourage workers to participate in decisions-making, relate reward to performance and listen and take responsibility of their actions. Managers must explain the criteria for job cuts. When possible, long-term strategies and innovation must be encouraged and the costs of outsourcing avoided.

Outsourcing strategies can be used as effective tools for competitive positioning when firms realize that people are business. However, they are not universal solutions to organizational problems and they are not simple or easy to develop and support. Implementation is a complex task that requires time and commitment; however, the payoffs can be enormous. Productivity, quality, customer satisfaction, and performance are likely to be improved by well implemented outsourcing programs tied to highly effective human resources strategies.

\section{References}

Baily, M. N., \& Farrell, D. (2004, April). Exploding the myths about offshoring. The McKinsey Global Institute 2004. Retrieved from http://www.mckinsey.com/ $\mathrm{mgi} /$ publications/myths.asp

Baily, M. N., \& Farrell, D. (2004). Is your job headed for Banglore? The myths and realities of outsourcing. The Milken Institute Review. Retrieved from http:// www.milkeninstitute.org/publications/review/2004_12/33_41mr24.pdf

Bartlett, B. (2004, July). How outsourcing creates jobs for American. National Center for Policy Analysis, 480.

Baruch, Y., \& Hind, P. (1999). Perpetual motion in organizations: Effective management and the impact of the new psychological contracts on "Survivor Syndrome." European Journal of Work and Organizational Psychology, 8(2), 295306. 
Beamon, B. M. (1999). Measuring supply chain performance. International Journal of Operations \& Production Management, 19(3), 275-292.

Bender, P. (1999). Market momentum in managing manpower. Outsourcing Journal. Retrieved from www.outsourcing_journal.com/issues

Bolumole, Y., Frankel, R., \& Nasland, D. (2007). Developing a theoretical framework for logistics outsourcing. Transportation Journal, 46(2), 35-54.

Cassale, F. J. (1996). Introduction to outsourcing. The Outsourcing Institute. Retrieved from http://www.outsourcing.com/howandwhy/topl0/main.htm.

Charara, J. (2004). Impact of outsourcing 'lasts years.' People Management, 2(4), $15-18$.

Chase, R. B., Nicholas J. A., \& Jacobs, R. F. (2000). Operations management for competitive advantage. Chicago: Irwin Publishing Co.

Corbett, M. F. (1996). Redefining the corporation: Bringing order to a new industry. Outsourcing Leadership Forum, 1-7.

Corbett, M. F. (1999). Multiple factors spur outsourcing growth. Outsourcing Journal. Retrieved, from www.Outsourcing-Journal.com/issues/jan1999-index. html.

Corbett, M. F. (2002). Executives reveal the future of outsourcing. Firmbuilder. Retrieved from http://www.firmbuilder.com.

Crane, D. (1999). Renewed focus on financial performance. Outsourcing Journal. Retrieved from www.Outsourcing-Journal.com/issues/.

Crolius, R. W. (2006, February). America's workforce crisis. American Ceramic Society, 2,8 .

Crosby, P. (1979). Quality is free: The art of making quality contain. New York: McGraw-Hill.

Dobbs, L. (2004). Exporting America: Why corporate greed is shipping American jobs overseas. New York: Time Warner Book Group.

Dobbs, L. (2004, August 27). A Home advantages for U.S. corporations. CNN. Retrieved from http://www.cnn.com/2004/US/08/27/home.advantage/.

Donahoe, D. N., \& Pecht, M. (2003). Are U.S. jobs moving to China? IEEE Transactions on Components and Packaging Technologies, 26(3), 682- 686.

Drezner, D. (2004, May). The outsourcing bogeymen. Council of Foreign Relations: Foreign Affairs. Retrieved from http://www.foreignaffairs. org/2004050l faessay 83304/daniel-w-drezner/the-outsourcing-bogeyman.html.

Elmuti, D. (2003). The perceived impact of outsourcing on organizational performance. Mid-American Journal of Business, 18(2). 
Engardio, P. (2006, June 3). The future of outsourcing: How it's transforming whole industries and changing the way we work. Business Week, 3969, 50-58.

Engardio, P., Bernstein, A., \& Kriplani, M. (2003, February 3). The new global shift. Business Week Online. Retrieved from http://www.businessweek.com/ magazine/content/03_05/b3818001.htm.

Engardio, P., Bernstein, A., Kripalani, M., Balfour, F., Grow, B., \& Greene, J. (2003, February 3). Is your job next? Business Week, 3818, 20-29.

Farrell, D. (2004). A richer future for India. The McKinsey Quarterly. Retrieved from http://www.mckinseyquarterly.com/article_page.aspx?ar $=1440 \& \mathrm{~L} 2+7 \& \mathrm{~L}$ $3=10 \&$ srid $=6 \& g$.

Farrell, D., \& Rosenfeld, J. (2005, December). US offshoring: Rethinking the response. McKinsey Global Institute. Retrieved from http://www.mckinsey.com/ mgi/publications/rethinking.asp.

Feulner, E. J. (2004, August 20). The truth about outsourcing. The Central New York Business Journal, 25.

Fitzpatrick, W. M., \& DiLullo, S. A. (2007). Outsourcing and the personnel paradox. Sam Advanced Management Journal, 72(3), 4-12.

Florida, R. (2004). America's looming creativity crisis. Harvard Business Review, $82(10), 122-136$.

Fraser, A., Kane, T., \& Schaefer, B. (2004, April). Ten myths about jobs and outsourcing. The Heritage Foundation. Retrieved from http://www.heritage.org/ Research/TradeandForeignAid/wm467.cfm?renderforprint=l.

Geyskens, I., Steenkamp, J. B., \& Kumar, N. (2006). Make, buy, or ally: A transaction cost theory meta-analysis. Academy of Management Journal, 49(3), 519543.

Griffiths, D. (2001). The theory and practice of outsourcing. STC Proceedings, pp. 112-117.

Hoffman, T., \& Thibodeau, P. (2003, April 29). Exporting IT jobs. Computerworld, pp. $10-14$.

HR FOCUS. (2009, August). Layoff: Survivor stress, pp. 10-16.

Irwin, D. (2004, January 29). Outsourcing is good for America. The Wall Street Journal, 243(19), Al6.

Jasper, W. (2003). Your job may be next. The New American, 19(5), 28-29.

Judge, W. O., \& Dooley, R. (2005). Strategic alliance outcomes: A transaction-cost economics perspective. British Journal of Management, 17, 23-37.

Kahn, J., \& Blumenthal, R. (2004, April 26). Made in the USA? Not anymore. The New York Times Upfront, pp.10-14. 
Kennedy, J. F., Holt, D. T., Ward, M. A., \& Rehg, M. T. (2002). The influence of outsourcing on job satisfaction and turnover intentions of technical managers. Human Resource Planning, 25(1), 23-31.

Kiplinger's Personal Finance. (2009, November). On the job and feeling guilty, pp. 5-8.

Klass, B., McClendon, J., \& Gainey, T. (2001). Outsourcing HR: The impact of organizational characteristics. Human Resource Management, 2(15), 45-54.

Kotabe, M., \& Murray, J. (1996). Determinants of intra-firm sourcing and market performance. International Business Review, 5(2), 121-135.

Kumar, S., \& Eickhoff, J. (2006). Outsourcing: When and how should it be. Information Knowledge Systems Management, 5, 245-259.

Lau, R. S., \& Hurley, C. N. (1997). Outsourcing Through Strategic Alliances. Production and Inventory Management Journal, 38(2), 52-57.

Lawler, E. E. (1975). Measuring the psychological quality of working life. In L. Davis \& A. Cherns (Eds.), The quality of work life (pp. 123-133). New York: Free Press.

Lazes, P., \& Savage, J. (2000). Embracing the future: Union strategies for the 21 st century. Journal for Quality \& Participation, 23(4), 18-23.

Lever, S. (1997). An analysis of managerial motivations behind outsourcing practices in human Resources. Human Resource Planning, 20(2), 37-47.

Li, X., \& Barnes, I. (2008). Proactive supply risk management methods for building a robust supply selection process when sourcing from emerging markets. Strategic Outsourcing: An International Journal, I(3), 252-267.

Marks, M. I., Mirvis, P. H., Hackett, E. J., \& Grady, J. F. (1986). Employee participation in a quality circle program: Impact on quality of work life, productivity, and absenteeism. Journal of Applied Psychology, 17(2), 61-69.

Mathur, N. (2006, January). The state of outsourced public services: A pain for the workers. PA Times. Retrieved from Ebscohost at Eastern Illinois University.

McCracken, B. (2002). New report: Most small businesses save significant sums through HR outsourcing. Outsourcing Center. Retrieved from http://www.outsourcing-hr.com/report.html.

Mol, M. J. (2007). Outsourcing: Design, process, and performance. Cambridge: New York.

Moses, A., \& Ahlstrom, P. (2008). Dimensions of change in make or buy decision processes. Strategic Outsourcing: An International Journal, I(3), 230-251.

Mott, P. E. (1972). The characteristics of effective organizations. New York: Harper and Row. 
Musico, C. (2008, January 30). Worldwide outsourcing market to grow $8.1 \%$ in '08. Destinationcrm.com. Retrieved from http://www.destinationcrm.com/Articles/ CRM-News/Daily-News/.

Narasimhan, R., \& Jayaram, J. (1998). Casual linkage in supply chain management: An exploratory study of North American manufacturing firms. Decision Sciences, 29(3), 579-605.

Nunnally, C. J. (1987). Psychometric theory (2nd ed.). New York: McGraw-Hill Book Company.

Overman, S. (1995, March). Saturn teams working and profiting. HR Magazine, $72-74$.

Outlay, C., \& Ranganathan, C. (2005). Exploring the downside of IT outsourcing: Outsourcing tactics, layoffs, and organizational outcomes. Americas Conference on Information Systems (AMCIS) - AMCIS 2005 Proceedings, pp. 20-27.

Reaser, L. (2004). Outsourcing of U.S. jobs: Threat or benefit? ABA Banking Journal, 96(2), 96.

Roberts, C. R. (2005). Outsourcing after-effects. Washington Times, pp. 6-8. Retrieved from http://www.washingtontimes.com.

Sahdev. (2004). Revisiting the survivor syndrome: The role of leadership in implementing downsizing. European Journal of Work and Organizational Psychology, I3(2), 165-196.

Shore, B. (1996). The legacy of downsizing: Putting the pieces back together. Business Forum, 2I(3 \& 4), 5-10.

Smith, P. C., Kendall., D. M., \& Hulin, D. L. (1969). The measurement of satisfaction in work and retirement. Chicago: Rand McNally.

Spector, P. E. (1997). Job satisfaction: Application, assessment, causes, and consequences. Thousand Oaks, CA: Sage.

Stonecipher, H. (2004). Outsourcing: The real issue. Executive Excellence, pp. 6-9

Study notes offshoring downside. (2004, March 4). CNN Money.

Survey of current and potential outsourcing end users. (1998). The Outsourcing Institute Membership.

The Dobbs report: Answers on outsourcing. (2004, March 12). CNN Money.

Tett, R. P., \& Meyer, J. P. (1993). Job satisfaction, organizational commitment, turnover intention, and turnover: Path analysis based on meta-analytic findings. Personnel Psychology, 46, 259-292.

Venkatraman, N. (2004), Offshoring without quilt: The debate about the ethics of offshoring misses the point that it represents the next generation of business practice. MIT Sloan Management Review, 45(3), 14-16. 
Vickery, S., Jayaram, J., Droge, C., \& Calantone, R. (2003). The effects of an integrative supply chain strategy on customer service and financial performance: An analysis of direct versus indirect relationships. Journal of Operations Management, 2I(5), 523-539.

Walsh, J., \& Deery, S. (2006). Refashioning organizational boundaries: Outsourcing customer service work. Journal of Management Studies, 43(3), 557-582.

Weidenbaum, M. (2004). Outsourcing: Pros and cons. Business Horizons, 48(4), 311-315.

Wood. (2009). Act now to prevent survivor syndrome. Business Forum, 8(2), 6-9.

Woodruff. (1995, May). Motivation: After the downsizing, Part 2. HR Magazine, pp. 40-43.

\section{Biographical Sketches of Authors}

Dean EImuti, Ph.D. is a professor and coordinator of management discipline in the Lumpkin School of Business and Applied Sciences at Eastern Illinois University. Previously he was employed for several years by multi-national corporations in the Middle East. He has published extensively (more than 90 journal articles) in the areas of quality, team based management, outsourcing, human resource challenges, and global competitiveness.

Julian Grunewald, MBA, is currently a graduate student at Eastern Illinois University. He is currently working on leadership, outsourcing and Supply Chain management. During his studies, he has earned several awards and scholarships, in addition to being a graduate assistant.

Dereje Abebe, MBA, is currently a graduate student at Eastern Illinois University. He has worked in training and administration for several years. He is currently working on various researches including supply chain, Entrepreneurship, and outsourcing. 
